\title{
Antibacterial activity of shrimp chitosan against some local food spoilage bacteria and food borne pathogens
}

\author{
MA Morhsed ${ }^{1,3 *}$, AA Bashir $^{1}$, M H Khan $^{1}$, and M K Alam ${ }^{2}$ \\ ${ }^{1}$ Department of Biotechnology and Genetic Engineering, Islamic University, Kushtia-7003, Bangladesh, ${ }^{2}$ Microbiology and Industrial Irradiation \\ Division, Institute of Food \& Radiation Biology, Bangladesh Atomic Energy Commission, Savar, Dhaka, Bangladesh, ${ }^{3}$ Department of Pharmacy, \\ North South University, Bashundhara, Baridhara, Dhaka-1229, Bangladesh.
}

(Received 23 January 2011; Accepted 14 April 2011)

\begin{abstract}
The objective of this study was to determine the more efficient antibacterial activity of chitosan among irradiated and nonirradiated form. Chitin was isolated from shrimp and then converted into chitosan. The initial molecular weight of chitosan was $1.6 \times 10^{6} \mathrm{Da}$ and after step by step pretreatments using alkali, acid and $\mathrm{H}_{2} \mathrm{O}_{2}$, the final molecular weight was found to be reduced to $2.7 \times 10^{4} \mathrm{Da}$ and the degree of deacetylation (DD) was $\mathbf{7 0 \%}$. Chemical treatments deproteinated and decalcified the chitin. Chitosan, the deacetylated form of chitin, was dissolved in lactic acid and then irradiated to perform antimicrobial activity. To conduct the experiment, seven different strains of bacteria were isolated from spoiled orange and it was found that chitosan was more effective to inhibit the growth of these bacteria. The more efficient result was found with irradiated chitosan than the non-irradiated one and the efficiency was consistently along with the increasing of the radiation dose. The best antimicrobial activity was observed with $32 \mathrm{kGy}$.
\end{abstract}

Key words: Chitin, Chitosan, antimicrobial activity.

Presently chitin and chitosan are continuously getting market among the farmers and businessmen. Now-a-days, chitosan applications are showing significantly positive effects in increasing yields of agricultural production in many countries. It is clear that chitin and chitosan are being used in fruits as a natural preservative due to its antimicrobial activity ${ }^{1-4}$.

Chitosan is the name used for low acetyl substituted forms of chitin and is composed primarily of glucosamine, 2 amino - 2 dexoy- $\mu$-D- glucose, known as $(1 \rightarrow 4)-2$ amino-2-deoxy-Dglucose. In recent years, there has been an increasing interest in finding alternatives to chemical bactericides and fungicides as they are safe, and with negligible risk to human health and environment ${ }^{5}$. Some satisfactory results have been reported using natural compounds such as chitosan ${ }^{6}$. The unusual anti-microbial activity of chitin, chitosan and their derivatives against different groups of microorganisms has received considerable attention in recent years ${ }^{7}$. It is also because of its unique physiochemical characteristics and biological activities ${ }^{8}$. Amongst various bioactive properties of chitosan, its antimicrobial activity has also received considerable interest due to problems associated with some chemical antimicrobial agents ${ }^{2}, 9$. Chitin acts as a chelating agent that selectively binds trace metals and thereby inhibits microbial growth ${ }^{10}$. Chitosan inhibits bacterial activity by inhibiting RNA and protein synthesis. Chitosan also exerts its antibacterial activity by acting as a chelating agent. It removes metals, trace elements or essential nutrients from bacteria causing distortion in cell growth and eventually death ${ }^{11}$. Chitosan acts as water binding agent and inhibits various enzymes ${ }^{12}$.

The natural antibacterial and/or antifungal characteristics of chitosan and its derivatives ${ }^{3,13-16}$ have resulted in their use in commercial disinfectants. Chitosan has several advantages over other types of disinfectants because it possesses a broader spectrum of antibacterial activity, and a lower toxicity for mammalian cells ${ }^{17}$. It is also easily biodegradable with gel forming ability at low $\mathrm{pH}^{18}$. Shrimp shells are an environmental waste material. So, extraction of chitin and chitosan from shrimp shells can be used as a suitable natural preservative that may have positive role for long term storage of chitosan coated orange. The objective of this work was to investigate the anti-microbial effects of chitosan against orange spoilage microorganisms.

Fresh, healthy ripe and spoiled oranges of suitable sizes were collected from different markets of Dhaka, Bangladesh and transported to the laboratory for experiment. Ten grams of sample (orange) was taken in a sterile conical flask containing $90 \mathrm{ml}$ of distilled water and homogeneous suspension of the sample up to $10^{-5}$ dilution was made and inoculated onto nutrient agar media. Staphylococcus aureus, Proteus spp. Bacillus megaterium, Bacillus cereus, Bacillus subtilis, Streptococcus spp. and Staphylococcus epidermidis were isolated from the rotten oranges and was identified by biochemical tests. These isolates were used in the experiment. 
Shrimp shells were collected from local market, transported to the laboratory, processed, washed, sun dried and then cut into pieces for utilization to extract chitin and chitosan. To remove protein from shrimp shell, 5 liters of $40 \% \mathrm{NaOH}(\mathrm{w} / \mathrm{v})$ was added to $2 \mathrm{Kg}$ of shrimp shell and the deproteination process was led for 72 hours. After deproteination, the shells were washed with water. The shells then were treated with $400 \mathrm{ml}$ of $4 \% \mathrm{HCl}$ for $20-24$ hours to remove calcium, then washed with water and dried. Thereafter, deproteinated and decalcified shells were the chitin ${ }^{1}$.

To produce chitosan, $200 \mathrm{~g}$ dried deproteinated and decalcified chitins were moisturized with $200 \mathrm{ml}$ water and then deacetylated by treating with $20 \mathrm{M} \mathrm{NaOH}$ solution for 48 hours. After deacetylation, chitosan flakes were washed, squeezed and dried in a forced air oven at $60-70^{\circ} \mathrm{C}^{1}$.

A $2 \%$ working solution of chitosan was made by dissolving in $3 \%$ lactic acid. This solution was irradiated with a dose of $0 \mathrm{kGy}$, $8 \mathrm{kGy}, 16 \mathrm{kGy}$ and $32 \mathrm{kGy}$ respectively to reduce the molecular weight and to increase degree of deacetylation (DD) more than $70 \%{ }^{19}$.

Irradiated ( $8 \mathrm{kGy}, 16 \mathrm{kGy}$ and $32 \mathrm{kGy}$ ) and non-irradiated chitosan solutions were used for antibacterial activity. One hundred micro liter of $10^{7} \mathrm{cfu} / \mathrm{ml}$ of bacterial suspension was spread plated onto nutrient agar media, and then irradiated and non-irradiated chitosan solution, and lactic acid were spread over the inoculated nutrient media. The plates were then incubated at $37^{\circ} \mathrm{C}$ for 24 hours. After incubation, the presences of bacterial numbers were enumerated.

Each of the isolated bacterial strain was diluted to $10^{7} \mathrm{cfu} / \mathrm{ml}$, and 100 il of bacterial suspension was spreaded over nutrient agar media. Wells $(8 \mathrm{~mm})$ were made in the plates by using a borer. The holes were then filled with appropriate amount of sterilized irradiated ( $8 \mathrm{kGy}, 16 \mathrm{kGy}$ and $32 \mathrm{kGy}$ ), non radiated chitosan solution and lactic acid followed by incubation at $37^{\circ} \mathrm{C}$ for 24 hours. After incubation, the zone of inhibition was observed and recorded. Aceptic condition was maintained very strictly.

The initial bacterial load was found to be $4.6 \times 10^{6} \mathrm{cfu} / \mathrm{g}$ in spoiled orange. Biochemical analysis reveals the presence of Staphylococcus aureus, Proteus spp. Bacillus megaterium, Bacillus cereus, Bacillus subtilis, Streptococcus spp. and Staphylococcus epidermidis among the isolates. Anti-bacterial activity of chitosan was performed against all of these strains. Both the non-irradiated and irradiated chitosan showed antimicrobial response but the better result was found in case of irradiated chitosan (Table-1, 2).

Lactic acid also showed antimicrobial activity due to its low $\mathrm{pH}$. It was also found that the antimicrobial activity of the chitosan was gradually increased by increasing the radiation dose. Though $8 \mathrm{kGy}, 16 \mathrm{kGy}$ and $32 \mathrm{kGy}$ treatments were used but the most effective result was obtained from $32 \mathrm{kGy}$ treatment which has consistency with some other studies ${ }^{1}$.

Table 1. Anti-bacterial activity of irradiated and non-irradiated chitosan.

\begin{tabular}{|c|c|c|c|c|c|c|c|}
\hline \multirow[t]{2}{*}{ S No. } & \multirow[t]{2}{*}{ Strain No. } & \multirow[t]{2}{*}{ Control } & \multirow[t]{2}{*}{ LacticAcid } & \multicolumn{4}{|c|}{ Radiation dose } \\
\hline & & & & $0 \mathrm{kGy}$ & $8 \mathrm{kGy}$ & $16 \mathrm{kGy}$ & $32 \mathrm{kGy}$ \\
\hline 1. & Staphylococcus aureus & $1.4 \times 10^{5}$ & $2.3 \times 10^{4}$ & $3.2 \times 10^{2}$ & $7.3 \times 10^{1}$ & $3.8 \times 10^{1}$ & $1.1 \times 10^{1}$ \\
\hline 2. & Proteus spp. & $1.0 \times 10^{5}$ & $3.2 \times 10^{4}$ & $1.3 \times 10^{2}$ & $9.1 \times 10^{1}$ & $6.3 \times 10^{1}$ & $2.7 \times 10^{1}$ \\
\hline 3. & Bacillus megaterium & $1.3 \times 10^{5}$ & $5.1 \times 10^{4}$ & $2.1 \times 10^{2}$ & $8.2 \times 10^{1}$ & $4.2 \times 10^{1}$ & $1.4 \times 10^{1}$ \\
\hline 4. & Bacillus cereus & $1.7 \times 10^{5}$ & $1.3 \times 10^{4}$ & $1.2 \times 10^{2}$ & $5.2 \times 10^{1}$ & $2.3 \times 10^{1}$ & $1.9 \times 10^{1}$ \\
\hline 5. & Bacillus subtilis & $1.6 \times 10^{5}$ & $2.1 \times 10^{4}$ & $1.7 \times 10^{2}$ & $6.4 \times 10^{1}$ & $5.4 \times 10^{1}$ & $2.1 \times 10^{1}$ \\
\hline 6. & Streptococcus spp. & $1.25 \times 10^{5}$ & $2.0 \times 10^{4}$ & $2.3 \times 10^{2}$ & $7.4 \times 10^{1}$ & $4.6 \times 10^{1}$ & $2.9 \times 10^{1}$ \\
\hline 7. & Staphylococcus epidermidis & $2.5 \times 10^{5}$ & $1.9 \times 10^{4}$ & $4.1 \times 10^{2}$ & $8.3 \times 10^{1}$ & $3.9 \times 10^{1}$ & $4.1 \times 10^{1}$ \\
\hline
\end{tabular}

* Data are expressed as cfu/ml.

Table 2. Antimicrobial properties of chitosan dissolved in 3\% lactic acid against different bacteria tested using well method. (Well size $=8 \mathrm{~mm}$ )

\begin{tabular}{|c|c|c|c|c|c|c|}
\hline \multirow[t]{2}{*}{ S.No. } & \multirow[t]{2}{*}{ Strain } & \multicolumn{5}{|c|}{ Zone of inhibition by irradiated and Non-irradiated chitosan } \\
\hline & & Lactic acid & $0 \mathrm{kGy}$ & 8 kGy & $16 \mathrm{kGy}$ & $32 \mathrm{kGy}$ \\
\hline 1. & Staphylococcus aureus & 3 & 4 & 6.5 & 9 & 10 \\
\hline 2. & Proteus spp. & 3.7 & 7 & 7.5 & 7.5 & 7.5 \\
\hline 3. & Bacillus megaterium & 3.2 & 6 & 8 & 8 & 9 \\
\hline 4. & Bacillus cereus & 3.6 & 6 & 7.5 & 8 & 9 \\
\hline 5. & Bacillus subtilis & 4.1 & 7 & 8 & 9 & 9.5 \\
\hline 6. & Streptococcus spp. & 4.5 & 7 & 7.5 & 8.5 & 9 \\
\hline 7. & Staphylococcus epidermidis & 3.2 & 4 & 6 & 7 & 6 \\
\hline
\end{tabular}

* Data are expressed in millimeter (mm). 
The country, Bangladesh, got a golden tradition of exporting large amount of shrimps/lobsters to the foreign countries. As a result, Bangladesh is producing a big amount of shrimp shell as wastes every year. This natural waste would be used as an important source of value added product that might be used as a substance for its application in a new horizon or to use as a supplement or even may be used as a complement of existing compound. Therefore, the aim of this research work was to extract chitin from shrimp wastes and their conversion into chitosan for assessing its utility as an antibacterial agent for using various purposes.

\section{Acknowledgements:}

We are thankful to all of the departmental stuffs of Microbiology and Industrial Irradiation Division, Institute of Food and Radiation Biology (IFRB), Atomic Energy Research Establishment (AERE), Bangladesh Atomic Energy Commission, Ganakbari, Savar, Dhaka, Bangladesh.

\section{Reference}

1. AH Sardar, H Rashid, MK Munshi and R Begum. 2008. Shelf-life extension of mango using natural preservative chitosan at room temperature. Bangl J Env Res. 6:31-37.

2. Roller S and Covill N. 1999. The antifungal properties of chitosan in laboratory media and apple juice. Int J Food Microbiol. 47: 67-77.

3. El Ghaouth, Arul J, Grenier J and Asselin A. 1992. Antifungal activity of chitosan on two pathogens of strawberry fruits. Phytopathology. 82: $398-402$.

4. Savage PJ and Savage GP. 1994. The Effect of Coating Apples on the Quality of Stored Apples. Pro Nutri Soc New Zealand. 19: 129-133.

5. Peter MG. 1995. Applications and environmental aspects of chitin and chitosan. J.M.S.-Pure Applied Chemistry. 32: 629-640.

6. Muzzarelli RAA. 1983. Chitin and its derivatives: New trend of applied research. Carbohydrate Polymer. 3:53-75.

7. Yalpani M., Johnson F and Robinson, LE 1992. Chitin, Chitosan: Sources, Chemistry, Biochemistry, Physical Properties and Applications, Elsevier, Amsterdam.
8. No HK and Meyers S.P. 1997. Preparation and production of chitin and chitosan. In: Muzzarelli R.A.A., Peter M.G. (eds): Chitin Handbook. Grottammare, European Chitin Society: 475-489.

9. Guo Z, Chen R, Xing R, Liu S, Yu H, Wang P, Lia B and Lia P. 2006. Novel derivatives of chitosan and their antifungal activities in vitro. Carbohydrate Research. 341: 351-354.

10. Cuero RG, Duffus E, Osuji G, and Pettit R. 1991. Aflatoxin Control in Preharvest Maize: Effects of Chitosan and Microbial Agents. J Agri Sci. 117:165-169.

11. Gristina AG. 1987. Biomaterial centered infection: microbial adhesion versus tissue integration. Science. 237: 1588-1595.

12. Young DY, Kohle H, and Kauss H. 1982. Effect of chitosan on membrane permeability of suspension-cultured Glycine max and Phaseolus vulgaris cells. Plant Physiol. 70:1449-1454.

13. Papineau AM, Hoover DG, Knorr D, and Farkas DF. 1991. Antimicrobial effect of water-soluble chitosans with high hydrostatic pressure. Food Biotechnol. 5: 45-57.

14. Sudarshan NR, Hoover DG, and Knorr D. 1991. Antibacterial action of chitosan. Food Biotechnol. 6: 257-272.

15. Kim CH, Cho JW and Chun HJ. 1997. Synthesis of chitosan derivatives with quaternary ammonium salt and their antibacterial activity. Polymer Bulletin. 38:387-393.

16. Chung YC, Su YP, Chen CC, Jia G, Wang HI, Wu JCG and Lin JG. 2004. Relationship between antibacterial activity of chitosan and surface characteristics of cell wall. Acta Pharmacol Sci. 25: 932936.

17. Liu XF, Guan YL, Yang DZ, Li Z and Yao KD. 2001. Antibacterial action of chitosan and carboxymethylated chitosan. J Appl Pol Sci. 79:1324-1335.

18. Muzzarelli RAA. 1999. Native, industrial and fossil chitins. In: Jolles, P, Muzzarelli, RAA. (Eds.), Chitin and Chitinases. Berkhauser Verlag, Basel, Switzerland. pp1-3.

19. Cheng-Ho Chen, Fang-Yu Wang and Zu-Pei Ou. 2004. Deacetylation of â-chitin. I. Influence of the deacetylation conditions. J App Poly Sci. 93 (5): 2416-2422.

20. Wang W, Bo S, Li S and. Qin W. 1991. Determination of the MarkHouwink equation for chitosans with different degree of deacetylation. International Journal of Biological Macromolecules. 13:281-285.

21. Won-Seok C, Kil-Jin A, Dong-Wook L, Myung-Woo B and Hyun-Jin P. 2002. Preparation of chitosan oligomers by irradiation. Poly Degra Stabil. 78 (3):533-538. 